PRZEMYSŁAW OSIEWICZ

Poznań

\title{
Integracja europejska w polityce zagranicznej Turcji za rządów Partii Sprawiedliwości i Rozwoju (AKP)
}

\section{Wprowadzenie}

Na początku drugiej dekady XXI wieku Turcja bez wątpienia należy do grona kluczowych państw o statusie mocarstw regionalnych. Jej bieżąca polityka oddziałuje na prawie wszystkie sąsiednie państwa, a także niemalże cały świat muzułmański. Nie jest dziełem przypadku, iż uczestnicy tak zwanej arabskiej wiosny z 2011 roku z uznaniem spoglądają na dotychczasowe osiągnięcia i dokonania tureckich władz, a obecny premier Recep Tayyip Erdoğan powoli staje się bohaterem mieszkańców Tunezji, Egiptu czy Autonomii Palestyńskiej. Dzisiaj Turcja nie kojarzy się już w świecie arabskim jedynie z dawnym uciskiem w ramach Imperium Osmańskiego czy późniejsza, niezrozumiałą dla większości ówczesnych muzułmanów, modernizacją Turcji za rządów kemalistów, której podstawę stanowiły, między innymi, sekularyzacja i laicyzacja państwa. Dzisiaj nazwa Turcji jest na Bliskim Wschodzie synonimem niezależności, skutecznej polityki zagranicznej oraz sukcesu gospodarczego.

Niemniej należy wyraźnie podkreślić, iż obecna pozycja Turcji wynika przede wszystkim ze skutecznej polityki zagranicznej, prowadzonej w ciągu ostatnich kilkunastu lat. Jeszcze w pierwszej połowie lat dziewięćdziesiątych można było przypuszczać, że to właśnie Turcja znajdzie się w grupie państw, które w największym stopniu stracą na znaczeniu po zakończeniu zimnej wojny. Stany Zjednoczone nie potrzebowały już Turcji tak bardzo jak przed 1991 rokiem, gdy, będąc przecież członkiem Organizacji Paktu Północnoatlantyckiego, bezpośrednio graniczyła ze Związkiem Radzieckim. Ponadto, Turcja miała napięte stosunki praktycznie z każdym sąsiednim państwem, począwszy od Bułgarii i Grecji, a skończywszy na Iranie czy Syrii. Tym samym uwarunkowania wewnętrzne i zewnętrzne wymuszały na Turcji konieczność zmiany podejścia w stosunku do głównych problemów wewnętrznych (kwestia kurdyjska, liczne ograniczenia systemu demokratycznego po 1980 roku, uprzywilejowana pozycja armii w państwie, przypadki łamania praw człowieka) oraz przedefiniowanie głównych celów polityki zagranicznej (zwłaszcza poprawa stosunków z Grecją, modyfikacja stanowiska odnośnie kwestii cypryjskiej, normalizacja stosunków z państwami arabskimi i Iranem). Jednakże rządzące elity, zdominowane przez kemalistów oraz generalicję, nie były przygotowane ani na głębokie reformy wewnętrzne, ani tym bardziej na jakiekolwiek istotne zmiany $\mathrm{w}$ ramach prowadzonej polityki zagranicznej. Przedstawiciele tureckich władz obawiali się, że jakiekolwiek zmiany systemowe zostaną odebrane przez społeczeństwo 
jako oznaka słabości i mogłyby poważnie zagrozić republikańskiemu charakterowi państwa ${ }^{1}$.

Sytuacja zmieniła się diametralnie dopiero po dojściu do władzy Partii Sprawiedliwości i Rozwoju (AKP - Adalet ve Kalkınıma Partisi) w listopadzie 2002 roku. Od samego początku nowy rząd starał się przede wszystkim przeprowadzić szereg reform wewnętrznych, poprawić oraz zintensyfikować stosunki z sąsiednimi państwami, uregulować wszelkie sporne kwestie i odbudować/rozszerzyć polityczną oraz gospodarczą strefę wpływów na Bliskim Wschodzie oraz w Azji Centralnej. Tym samym przedstawiciele AKP wyszli poza ramy dotychczasowej polityki zagranicznej, której podstawę stanowiło przede wszystkim utrzymywanie jak najlepszych stosunków ze Stanami Zjednoczonymi oraz z innymi państwami Zachodu, a także bliska współpraca z Izraelem.

W tym kontekście pojawia się pytanie o prounijny, europejski kierunek w polityce zagranicznej Turcji po 2002 roku. Począwszy od pierwszego wyborczego zwycięstwa AKP pojawiały się opinie, że Turcja za rządów tej partii może odwrócić się od Europy i próbować związać z innymi państwami na Bliskim Wschodzie. Pojawiały się również opinie, że być może to unijnym politykom będzie wkrótce bardziej zależeć na przyjęciu Turcji aniżeli tureckim władzom na wprowadzeniu swego państwa do UE². Ku zaskoczeniu wielu komentatorów i analityków tureckiej sceny politycznej, rząd zdominowany przez konserwatywną AKP od samego początku deklarował intensyfikację działań celem uzyskania pełnoprawnego członkostwa w UE. I to w stopniu o wiele większym aniżeli rządzący z krótkimi przerwami do 2002 roku kemaliści. Co więcej, słowa i deklaracje czołowych polityków AKP znalazły wkrótce potwierdzenie w konkretnych działaniach podejmowanych przez rząd. Obecnie tureckie władze nadal deklarują chęć przystąpienia do Unii Europejskiej, choć poparcie dla idei członkostwa w społeczeństwie wyraźnie spada, mnożą się problemy polityczne, a negocjacje akcesyjne utkwiły w martwym punkcie.

W tym kontekście należałoby postawić pytanie dotyczące prounijnego kierunku w polityce zagranicznej Turcji w okresie rząów Partii Sprawiedliwości i Rozwoju w latach 2002-2011, czyli od pierwszego wyborczego zwycięstwa aż do sukcesu

1 Po sukcesie rewolucji i przekształceniu Iranu z cesarstwa w państwo teokratyczne w 1979 roku, tureckie władze poważnie obawiały się możliwości powtórzenia tego scenariusza także w ich państwie. Chociaż szyickie idee promowane przez ajatollaha Chomeiniego nie trafiały na podatny grunt w zdominowanej wyraźnie przez sunnitów Turcji, sam przykład stanowił zagrożenie. Tym bardziej, że od początku lat siedemdziesiątych tureckie społeczeństwo żyło w cieniu terroru ze strony rozmaitych grup nacjonalistycznych oraz lewackich. Jakakolwiek poważna destabilizacja sytuacji politycznej mogła doprowadzić do nieodwracalnych zmian. W tym należy upatrywać, miedzy innymi, przyczyn wojskowego zamachu stanu z 1980 roku. Więcej na ten temat zob. E. Özbudun, Ö. F. Gençkaya, Democratization and the Politics of Constitution Making in Turkey, Central European University Press, Budapest 2009; Turkey Since 1970: Politics, Economics, and Society, pod red. D. Lovatt, Palgrave Macmillan, Basingstoke 2001.

2 Argumenty dotyczyły przede wszystkim wyjątkowego geopolitycznego położenia Turcji oraz możliwego, kierowanego przez nią rozwoju procesu integracyjnego, na przykład, w regionie Bliskiego Wschodu. Tym samym powrócił temat Turcji jako geopolitycznego pomostu pomiędzy Azją a Europa, swego rodzaju politycznego, gospodarczego i kulturowego łącznika pomiędzy kontynentami. Więcej zob. P. Osiewicz, Turcja - geopolityczny pomost między Azją a Europq?, „Rocznik Integracji Europejskiej" 2010, nr 4. 
w wyborach parlamentarnych z czerwca 2011 roku. Czy proeuropejska polityka Turcji ewoluowała, czy można dostrzec jakiekolwiek prawidłowości lub zmiany? Ponadto, warto znaleźć odpowiedź na pytanie czy w ramach samej AKP wszystkie liczące się frakcje opowiadają się za integracją Turcji z UE. Niniejszy artykuł stanowi próbę znalezienia odpowiedzi na powyższe pytania.

\section{Prounijna polityka Turcji przed 2002 rokiem}

Turcja została państwem stowarzyszonym z Europejską Wspólnotą Gospodarczą (EWG) już w 1963 roku. Od tego roku można mówić o prointegracyjnym nurcie w polityce zagranicznej Turcji, choć początków zdecydowanie proeuropejskiej, prozachodniej orientacji należy upatrywać już w momencie utworzenia republiki w 1923 roku. Podstawowym celem szeregu reform przeprowadzonych przez Mustafę Kemala Atatürka w latach dwudziestych i trzydziestych XX wieku była stopniowa europeizacja Turcji zarówno pod względem prawnym i politycznym, jak również światopoglądowym ${ }^{3}$.

$\mathrm{Z}$ czasem zarówno w państwach członkowskich, jak i w samej Turcji zaczęły pojawiać się głosy dotyczące ewentualnego przystapienia tego państwa do EWG. Przystąpienie Turcji miało stanowić przeciwwagę dla planowanego przyjęcia Grecji oraz umocnić polityczne i gospodarcze związki Turcji z Zachodem. Było to szczególnie istotne i korzystne dla obu stron w kontekście zimnowojennej konfrontacji ze Związkiem Radzieckim. Ponadto, realizacja takiego scenariusza była też pożądana z punktu widzenia Stanów Zjednoczonych. Jednakże turecki rząd zdecydował się złożyć wniosek o przyznanie członkostwa dopiero w 1987 roku i to w najmniej dogodnym momencie. Przede wszystkim pozycja międzynarodowa Turcji uległa znacznemu osłabieniu po przewrocie wojskowym z 1980 roku. Kilka lat rządów armii oraz będąca ich owocem Konstytucja z 1982 roku nie tylko podważyły demokratyczne podstawy państwa, ale pozwoliły również na systemową dyskryminację rozmaitych mniejszości etnicznych (Kurdowie) czy wyznaniowych (alewici), na przykład, pod pozorem zagrożenia dla „tureckości” państwa czy porządku publicznego.

Chociaż wniosek został odrzucony, Turcja uzyskała przynajmniej sprecyzowane kryteria, jakie musiałaby spełnić rozważając złożenie kolejnego wniosku. Pierwsza połowa lat dziewięćdziesiątych upłynęła jednak pod znakiem napięć w stosunkach grecko-tureckich, które skutecznie blokowały prounijne aspiracje Turcji. Dodatkowo, tureckie władze prowadziły zachowawczą politykę, którą niektórzy, negatywnie nastawieni analitycy nazywali turecką strategią peryferyjną ${ }^{4}$ Z kolei Gencer Özcan określił

3 Zob. więcej: Men of Order: Authoritarian Modernization Under Atatürk and Reza Shah, pod red. T. Atabaki, E. J. Zürcher, I. B. Tauris, New York 2004.

${ }_{4}$ W tym okresie działania Turcji koncentrowały się przede wszystkim na zacieśnianiu współpracy z takimi państwami jak Izrael, Jordania, Azerbejdżan czy Ukraina. Co ciekawe, w ramach polityki bezpieczeństwa nadal obowiązywała doktryna 2,5 wojny autorstwa Sükrü Elekdağa. W ramach tej koncepcji tureckie siły zbrojne miały być gotowe do równoczesnego prowadzenia dwóch wojen, na przykład, na zachodzie z Grecją i na wschodzie z Syrią oraz jednej wojny wewnętrznej (półwojna z kurdyjską partyzantką). Koncepcja Elekdağa przypominała zimnowojenną doktrynę amerykańską, ale oczywiście na o wiele mniejszą skalę. 
turecką politykę zagraniczną z lat 1995-1999 mianem okresu asertywnej dyplomacji5. Sytuacja zmieniła się diametralnie dopiero w 1999 roku, gdy w wyniku tak zwanej dyplomacji sejsmicznej znaczącej poprawie uległy relacje Turcji z Grecją. Zbliżenie polityczne pomiędzy Atenami i Ankarą umożliwiło przyznanie Turcji statusu państwa kandydującego. Niemniej, Turcja po raz kolejny nie uzyskała przybliżonej daty rozpoczęcia negocjacji akcesyjnych, nie wspominając w ogóle o możliwej dacie przystąpienia. Jak się miało wkrótce okazać, rozmowy tureckich władz z Unią Europejską utkwiły w martwym punkcie aż do momentu dojścia do władzy AKP w listopadzie 2002 roku, choć należy docenić fakt przeprowadzenia w tym okresie licznych reform wewnętrznych i zmian legislacyjnych, na przykład, pierwszej rewizji Kodeksu karnego w roku 2001 lub zmian w Konstytucji, wprowadzonych w październiku 2001 roku Bez ich przeprowadzenia droga do otwarcia negocjacji akcesyjnych mogłaby okazać się znacznie dłuższa.

Niespodziewane zwycięstwo Partii Sprawiedliwości i Rozwoju w wyborach parlamentarnych w listopadzie 2002 roku otworzyło nowy rozdział w relacjach Turcji z Unią Europejską. Warto w tym miejscu przypomnieć, że wygrana AKP wywołała konsternację wśród elit rządzących w państwach zachodnich, choć sama kampania wyborcza tej partii miała wyraźnie prounijny charakter. $Z$ kolei kemaliści zarzucali zwycięskiej AKP ukrywanie jej prawdziwego, wyznaniowego charakteru, chęć osłabienia powiązań politycznych i ekonomicznych z Zachodem oraz przekształcenia Turcji w państwo wyznaniowe. Jednak, jak się miało wkrótce okazać, obawy te były nieuzasadnione. Nowy rząd nie tylko zintensyfikował współpracę z Unią Europejską, lecz także kontynuował (Grecja) lub rozpoczął proces normalizacji stosunków z sąsiednimi państwami (Iran, Syria). Sukcesy w polityce zagranicznej zaczęły się przekładać na wymierne korzyści z handlu międzynarodowego, a te z kolei na wzrost dochodu narodowego i poziom życia obywateli. Kolejne wyborcze sukcesy AKP nie stanowiły zatem zaskoczenia.

Ostatnim wyraźnym potwierdzeniem politycznych wpływów oraz siły Partii Sprawiedliwości i Rozwoju było kolejne zwycięstwo w wyborach parlamentarnych w czerwcu 2011 roku. Jednocześnie, co warte podkreślenia, AKP po dziewięciu latach rządów, przy bardzo wysokiej frekwencji (83,16\% uprawnionych), osiagnęła najlepszy w swej historii wynik - 49,8\%. W 2002 roku było to $34,3 \%$, a w $2007-46,6 \%$. Niemniej, system rozdzielania mandatów sprawił, że, paradoksalnie, AKP jednocześnie otrzymała ich najmniej w historii - 327. Dla porównania, w 2002 roku były to aż 363 miejsca $^{7}$.

\section{Polityka zagraniczna Turcji za rządów AKP: główne cele i kierunki}

Niemalże od samego początku rządów AKP głównym autorem nowej polityki zagranicznej jest Ahmet Davutođlu - polityk AKP, doradca premiera Erdoğana, a obecnie

5 G. Özcan, Turkey's Changing Neighbourhood Policy, Friedriech Ebert Stiftung Istanbul, Briefing Paper September 2004.

6 Turkey and Europe: the Way Ahead, International Crisis Group, Europe report No. 184 of 17 August 2007, s. 9.

7 A. Çarkoğlu, Turkey's 2011 General Elections: Towards a Dominant Party System?, „Insight Turkey" 2011, vol. 13, no. 3, s. 47. 
szef Ministerstwa Spraw Zagranicznych. Jeszcze przed wyborami w 2001 roku opublikował książkę zatytułowaną Stratejik derinlik (Strategiczna głębia), w której określił pożądane, najkorzystniejsze z punktu widzenia Turcji, kierunki w polityce zagranicznej ${ }^{8}$. W ramach swej koncepcji Davutoğlu wyróżnił politykę eliminacji problemów z państwami sąsiednimi (zero problems with neighbours policy), która zakładała uregulowanie wszelkich kwestii spornych z sąsiadami jako podstawę umacniania pozycji Turcji w regionie. Koncepcja Ahmeta Davutoğlu okazała się na tyle skuteczna, iż w kolejnych latach doszło do poprawy stosunków Turcji chociażby z takimi państwami jak Grecja, Syria, Iran, a nawet Armenia. Jej założenia realizowali dwaj poprzednicy ministra Davutoğlu: Abdullah Gül oraz Ali Babacan.

Oprócz licznych problemów wewnętrznych, rozmowy Turcji z przedstawicielami Komisji Europejskiej komplikowała nadal nieuregulowana sytuacja na Cyprze. Dla premiera Erdoğana stało się jasne, że rozwiązanie kwestii cypryjskiej może stanowić w przyszłości jeden z warunków przyjęcia Turcji do UE, a nawet samego rozpoczęcia negocjacji akcesyjnych. Grekocypryjczycy argumentowali, że nie można wyobrazić sobie sytuacji, w której jedno z państw członkowskich UE nie uznaje i dodatkowo de facto okupuje część terytorium innego państwa członkowskiego ${ }^{9}$. I chociaż stanowisko tureckich władz było odmienne, rząd w Ankarze zaczął wywierać presję na kierownictwo Turkocypryjczyków, a zwłaszcza prezydenta nieuznawanej przez społeczność międzynarodową Tureckiej Republiki Północnego Cypru - Raufa Denktaşa. W efekcie przedstawiciele obu cypryjskich społeczności powrócili do stołu rokowań na początku 2004 roku. Celem rozmów było doprowadzenie do zjednoczenia wyspy w ramach porozumienia wynegocjowanego pod auspicjami ONZ (tak zwany plan Annana), jeszcze przed formalnym przystąieniem Republiki Cypryjskiej do UE 1 maja 2004 roku $^{10}$. Dzięki temu cały Cypr miał zostać objęty stosowaniem prawa wspólnotowego, a wspierająca Turkocypryjczyków Turcja pozbyłaby się jednej z najistotniejszych przeszkód na drodze do pełnoprawnego członkostwa w UE. Warunkiem sine qua non wejścia

\footnotetext{
8 Więcej zob. A. Davutoğlu, Stratejik derinlik: Türkiye'nin uluslararasýkonumu, Küre Yayınları 2001.

${ }^{9}$ Do niedawna w polskiej literaturze naukowej na określenie dwóch cypryjskich społeczności używano nazw Grecy cypryjscy oraz Turcy cypryjscy. Podczas spotkania roboczego w dniu 10 grudnia 2010 roku zespół projektu „Cypr: dzieje, kultura, literatura” (projekt badawczy własny N N103 175838), pod kierownictwem prof. Małgorzaty Borowskiej (Uniwersytet Warszawski), podjął decyzję o stosowaniu odpowiednio nazw Grekocypryjczycy oraz Turkocypryjczycy.

10 Więcej na temat kwestii cypryjskiej w pierwszej dekadzie XXI wieku zob. A. Adamczyk, Cypr - dzieje polityczne, Wydawnictwo Dialog, Warszawa 2002; P. Osiewicz, Kolejna runda rokowań na Cyprze: szansa na przełom?, „Rocznik Integracji Europejskiej” 2008, nr 2; P. Osiewicz, Kwestia cypryjska i jej wptyw na negocjacje akcesyjne Turcji z Unia Europejska po 2004 roku, w: Turcja i Europa. Wyzwania i szanse, pod red. A. Szymańskiego, Polski Instytut Spraw Międzynarodowych, Warszawa 2011; P. Osiewicz, Kwestia cypryjska po 2004 roku: pojednanie czy podziat?, „Środkowoeuropejskie Studia Polityczne" 2006, nr 2; P. Osiewicz, Pokojowa regulacja kwestii cypryjskiej. Aspekty prawne i polityczne, Wydawnictwo Adam Marszałek, Toruń 2008; P. Osiewicz, Spór cypryjski: analiza stanowiska Turków cypryjskich przed i po 2004 roku. Zmiana czy kontynuacja?, w: Współczesne konflikty międzynarodowe i etniczne, pod red. D. K. Gemechu, Olsztyńska Szkoła Wyższa im. Józefa Rusieckiego, Olsztyn 2009; C. Palley, An International Relations Debacle: The UN Secretary-General's Mission of Good Offices in Cyprus 1999-2004, Hart Publishing, Oxford and Portland 2005.
} 
w życie porozumienia miało być jego zatwierdzenie przez członków obu społeczności w drodze dwóch równocześnie przeprowadzonych referendów. I chociaż do zjednoczenia nie doszło z powodu negatywnego wyniku referendum po stronie Grekocypryjczyków, społeczność światowa odnotowała zarówno głos na tak Turkocypryjczyków, jak również konstruktywną politykę tureckiego rządu. Jeśli dodać do tego szereg podjętych i zrealizowanych reform wewnętrznych (zmiany w Kodeksie karnym i Kodeksie postępowania karnego, zwiększenie cywilnej kontroli nad armią, zaostrzenie kar za torturowanie więźniów lub aresztantów, rozszerzenie praw mniejszości wyznaniowych i narodowych), decyzja Rady Europejskiej z grudnia 2004 roku, dotycząca otwarcia negocjacji z Turcją w październiku 2005 roku, staje się zrozumiała ${ }^{11}$.

W dniu oficjalnego otwarcia negocjacji członkowskich Turcji z Unią Europejską 3 października 2005 roku nic nie wskazywało jednak na to, że proces rokowań będzie aż tak powolny. Owszem, nie została określona nawet przybliżona data zakończenia rozmów, a UE zastrzegła, że zostaną zerwane, jeśli tureckie władze w sposób rażący naruszą prawa człowieka lub zasady demokratycznego państwa prawa, jednakże zamknięcie zaledwie jednego rozdziału negocjacyjnego w trakcie sześciu lat zaskoczyło nawet najbardziej sceptycznie nastawionych do tureckiego członkostwa ${ }^{12}$. Coraz częściej pojawiają się głosy, że jeśli Turcja w ogóle kiedykolwiek zostanie przyjęta do UE, to nie nastąpi to szybciej aniżeli w 2023 roku. Z pewnością moment byłby symboliczny - setna rocznica utworzenia republiki i początku europeizacji państwa. Nietrudno się jednak domyślić, iż tak odległe perspektywy są sceptycznie przyjmowane przez tureckie społeczeństwo, zmęczone poczuciem coraz to nowych warunków stawianych przez Brukselę.

Chociaż uprzednie uregulowanie kwestii cypryjskiej jeszcze w 2005 roku formalnie nie stanowiło warunku sine qua non przyjęcia Turcji do UE, wkrótce stało się oczywiste, że postęp w negocjacjach akcesyjnych nie będzie możliwy bez normalizacji sytuacji politycznej na wyspie oraz pomiędzy Republiką Turcji a Republiką Cypryjską. Jednocześnie AKP musiała liczyć się ze zdaniem tureckiej opinii publicznej, wrażliwej na próby złagodzenia stanowisk w kwestiach powszechnie postrzeganych za ogólnonarodowe. Fiasko planu Annana, brak nagrody dla Turcji i Turkocypryjczyków za konstruktywną postawę podczas referendów w kwietniu 2004 roku sprawiły, że rząd AKP miał bardzo ograniczone pole decyzyjne odnośnie kwestii cypryjskiej. Każde kolejne ustępstwo, jakikolwiek kompromis ze stroną Grekocypryjczyków, narażał rząd premiera Erdoğana na ataki opozycji oraz ryzyko porażki w kolejnych wyborach parlamentarnych. Wspomniane okoliczności tłumaczą przyczyny, dla których Turcja usztywniła swoje stanowisko w sprawie Cypru, licząc się nawet z możliwością zamrożenia rozmów w wybranych obszarach negocjacyjnych, co zresztą stało się faktem w grudniu 2006 roku. Co więcej, podczas wizyty na północnym Cyprze w lipcu 2011 roku premier Recep Tayyip Erdoğan stwierdził wręcz, iż Turcja nie popiera już rozwiązania

11 Y. Atasoy, Turkey, Islamists and Democracy: Transition and Globalization in A Muslim State, I.B. Tauris, London 2005, s. 189.

12 Więcej na temat przebiegu negocjacji akcesyjnych Turcji z UE w pierwszych latach rozmów zob. P. Osiewicz, Turcja na drodze do członkostwa w UE: uwarunkowania, przebieg oraz perspektywy negocjacji akcesyjnych, „Rocznik Integracji Europejskiej” 2009, nr 3. 
kwestii cypryjskiej na podstawie przekształcenia Cypru w państwo federalne, a co przewidywał plan Annana w 2004 roku, lecz opowiada się za wynegocjowaniem porozumienia, które pozwoli utrzymać obecny podział wyspy na dwa suwerenne państwa. Co więcej, szef tureckiego rządu wyraźnie podkreślił, że Turcja jest gotowa czasowo, jednostronnie zamrozić negocjacje członkowskie z Unią podczas prezydencji Republiki Cypryjskiej w Radzie UE w drugiej połowie 2012 roku, przede wszystkim ze względu na brak stosunków dyplomatycznych łączących Turcję z Republiką Cypryjską. Turecki premier zasugerował także, by państwa członkowskie wsparły proces rokowań na wyspie, aby udało się uregulować spór jeszcze przed objęciem prezydencji przez Grekocypryjczyków ${ }^{13}$.

Bez względu na różne oceny tureckiej polityki zagranicznej w samej Turcji, nie można odmówić jej skuteczności. Świadczy o tym, między innymi, rosnąca rola tego państwa chociażby w takich organizacjach jak Organizacja Konferencji Islamskiej czy w Organizacji Paktu Północnoatlantyckiego. Ponadto, Turcja poprawiła bądź umocniła swe relacje bilateralne $\mathrm{z}$ wieloma państwami na Bałkanach, Bliskim Wschodzie, w Azji Centralnej oraz w Afryce Północnej. Biorąc pod uwagę historyczny zasięg Imperium Osmańskiego, obecną politykę zagraniczną Turcji można określić mianem polityki neoosmańskiej. Arabska wiosna z 2011 roku została w dużej mierze zainspirowana przez polityczny i gospodarczy sukces Turcji. Nowe władze Tunezji i Egiptu konsultowały się z tureckim premierem, otwarcie przyznając, że turecki model powiązania wartości islamu z demokracją i gospodarką wolnorynkową będzie dla nich stanowił wzór przemian ${ }^{14}$.

Sytuację międzynarodową Turcji komplikuje jednak ponowne nasilenie wewnętrznego konfliktu pomiędzy rządem a mniejszością kurdyjską. Od początku lata 2011 roku we wschodniej Turcji zaobserwować można wzmożoną aktywność członków bojówek Partii Pracujących Kurdystanu (PKK) oraz liczne ataki na tureckich żołnierzy. Tym samym można stwierdzić, że promowana przez premiera Erdoğana polityka pojednania, której jednym z przejawów miało być złagodzenie represji oraz korzystne dla Kurdów zmiany konstytucyjne, zawiodła. Doprowadziła do tego przedwyborcza strategia lidera AKP, który publicznie, starając się zjednać sobie środowiska nacjonalistyczne, opowiadał się za aresztowaniami członków PKK, którym rok wcześniej obiecał amnestię. Ponadto, premier Erdoğan miał stwierdzić, iż gdyby lidera PKK Abdullaha Öcalana

13 D. Pirinova Sokolova, Contextualized dictionary of Turkish politics, „Turkish Review” 2011, vol. 1 , no. 5, s. 106.

${ }^{14}$ Zdaniem Alpera Y. Dede podstawy modelu tureckiego stanowią: 1) tolerancyjne podejście do wartości islamu; 2) brak dążenia do przekształcenia państwa w państwo wyznaniowe oparte, na przykład, na prawie szariatu; 3) umiejętne zorientowanie polityki w kierunku sukcesu gospodarczego i wymiernych korzyści, a nie ideologii; 4) proces pogłębiania procesu demokratyzacji. Do tego katalogu, tłumacząc rosnącą popularność Turcji w świecie arabskim, Dede dodaje coraz wyraźniejsze odcinanie się Turcji od Izraela. Wystarczy wspomnieć bardzo zdecydowaną reakcję premiera Erdoğana po ataku Izraelczyków na tak zwaną Flotyllę Wolności w 2010 roku, która zaowocowała znacznym wzrostem jego popularności wśród Palestyńczyków. Więcej zob. A. Y. Dede, The Arab Uprisings: Debating the Turkish Model, „Insight Turkey”2011, vol. 13, no. 2. Warto dodać, iż dokładnie przeciwnym modelem, za wyjątkiem stosunku do państwa Izrael, jest model irański, czym można z kolei tłumaczyć nieudany „eksport” idei rewolucji irańskiej. 
schwytano za jego rządów, najpewniej doprowadziłby do jego powieszenia ${ }^{15}$. Jednocześnie znaczenie kwestii kurdyjskiej wykracza poza granice Turcji. Stany Zjednoczone z niepokojem obserwują pościgi tureckich wojsk za partyzantami PKK już w głębi terytorium Iraku. Bez wątpienia zależy im na możliwie najlepszych stosunkach zarówno z tureckimi władzami, jak również z Kurdami, zwłaszcza w irackim Kurdystanie. Obecna sytuacja sprzyja natomiast destabilizacji w regionie. Kurdyjskie poparcie jest dla Amerykanów niezbędne nie tylko w kontekście kontroli wydarzeń w Iraku, ale może okazać się niemniej istotne w razie jakichkolwiek niepokojów społecznych $\mathrm{w}_{\text {Iranie }}{ }^{16}$. Co więcej, z perspektywy europejskiej niepowodzenie polityki pojednania z Kurdami tureckimi może stanowić cenny argument dla przeciwników tureckiej akcesji. Mogą pojawić się głosy, iż tureckie władze, wbrew oficjalnym deklaracjom, dyskryminują mniejszości narodowe czy religijne albo, że nie są w stanie zagwarantować bezpieczeństwa na własnym terytorium.

Jak zauważył Tolgahan Özkan, „rola Turcji na międzynarodowej scenie politycznej ulega zmianie ze statusu państwa peryferyjnego w ramach starego ładu międzynarodowego na państwo centralne w ramach nowego. W tym kontekście prowadzona jest coraz bardziej ambitna, wielowektorowa polityka zagraniczna. Proces trwa nadal, a tureckie władze starają się ustalić granice międzynarodowej aktywności politycznej. Każdy dyplomatyczny eksperyment rozszerza granice stosunków gospodarczych i przyczynia się do wzrostu eksportu. Polityka zagraniczna ministra Ahmeta Davutoğlu, który sam określa ją mianem czwartej odnowy, jest ściśle uwarunkowana przez szanse gospodarcze" ${ }^{\prime 1}$. Profesor Çiğdem Nas wskazuje z kolei, iż „,aktywna polityka zagraniczna prezentowana obecnie przez Turcję nie ogranicza się jedynie do regionu Bliskiego Wschodu, ale obejmuje także Afrykę i Amerykę Łacińską, czego przejawem jest otwieranie nowych ambasad, częste wizyty wysokiego szczebla oraz rosnąca liczba powiązań ekonomicznych i handlowych. Innym dowodem jest zniesienie w ostatnim okresie wymogu wizowego w odniesieniu do obywateli aż 61 państw, a także próby utworzenia unii celnej z udziałem Syrii, Libanu i Jordanii"”18. Graham E. Fuller już określił Turcję mianem państwa osiowego (pivotal state) w świecie muzułmańskim. W jego przekonaniu Turcja odzyskała należne jej miejsce w polityce eurazjatyckiej przede wszystkim dzięki dwóm czynnikom: zajęciu odpowiedniego stanowiska w sprawie wojny z terroryzmem po 11 września 2001 roku oraz dzięki sprawnej polityce rządów AKP ${ }^{19}$.

Chociaż zasięg obecnej polityki zagranicznej Turcji można określić mianem eurazjatyckiego, niektóre wypowiedzi tureckich polityków mogą budzić poważne wątpliwości. Na przykład, podczas wizyty w Niemczech w lutym 2011 roku premier Recep Tayyip Erdoğan określił strefę interesów Turcji jako rozciagającą się „od Kanału Su-

\footnotetext{
15 O. Matthews, A Civil War Revived, „Newsweek”, 14 November 2011, s. 13.

16 Według różnych szacunków, w Iranie mieszka od 6 do 8 milionów Kurdów, co stanowi około $10 \%$ irańskiego społeczeństwa.

17 T. Özkan, Turkey's Sphere of Influence Expands, „The Turkish Perspective” March-April 2011, s. 35.

${ }_{18}$ Ç. Nas, Turkey and the EU - Changing Dynamics, ,Turkish Policy Quarterly” Winter 2010/11, vol. 9 , no. 4 , s. 125 .

${ }_{19}$ G. E. Fuller, The New Turkish Republic: Turkey As a Pivotal State in the Muslim World, United States Institute of Peace Press, Washington D.C. 2010, s. 7-8.
} 
eskiego aż po Ocean Indyjski" ${ }^{20}$. W tym miejscu pojawia się zarazem pytanie o rolę i znaczenie Europy, a w szczególności Unii Europejskiej, w nowej polityce zagranicznej Turcji.

\section{Idea integracji europejskiej w tureckiej polityce zagranicznej w latach 2002-2011}

Unia Europejska z zadowoleniem przyjęła pierwsze deklaracje oraz działania podjęte przez nowy turecki rząd, zdominowany przez AKP. W raporcie Komisji Europejskiej oceniającym postęp Turcji na drodze do uzyskania pełnoprawnego członkostwa z 2003 roku znalazło się następujące stwierdzenie: „Unia przyjmuje do wiadomości determinację nowego tureckiego rządu odnośnie kontynuowania procesu reform i wzywa go do wyeliminowania wszelkich niedociagnięć w obszarze kryteriów politycznych, nie tylko w odniesieniu do zmian prawnych, ale zwłaszcza ich późniejszej implementacji” ${ }^{21}$. W innej części dokumentu znalazło się odniesienie do konkluzji szczytu Rady Europejskiej z czerwca 2003 roku, w którym Rada ,z zadowoleniem przyjęła do wiadomości konsekwencję, z jaką turecki rząd kontynuuje reformy, zwłaszcza w kontekście zmian legislacyjnych zaplanowanych do końca 2003 roku i wspiera jego bieżące starania celem wypełnienia kryteriów politycznych, które z kolei umożliwią otwarcie negocjacji akcesyjnych"22. I chociaż w kolejnym zdaniu wyraźnie podkreślono konieczność zintensyfikowania wysiłków w tym celu, liczyła się ogólna, pozytywna ocena pierwszego roku rządów AKP oraz jego starań o możliwie najszybsze rozpoczęcie negocjacji akcesyjnych. Pozytywna ocena przemian w Turcji była potwierdzana w kolejnych raportach, pomimo wielu uwag i zastrzeżeń.

Proeuropejskie nastawienie Partii Sprawiedliwości i Rozwoju znajduje potwierdzenie w wypowiedziach jej czołowych przedstawicieli. W wywiadzie przeprowadzonym w marcu 2011 roku minister spraw zagranicznych Ahmet Davutoğlu, zapytany o perspektywy udziału Turcji w procesie integracji europejskiej, oświadczył: „Przystąpienie do Unii Europejskiej jest i pozostanie naszym strategicznym celem. Negocjacje akcesyjne, rozpoczęte w 2005 roku, są kontynuowane na podstawie decyzji podjętych jednogłośnie przez państwa UE. Osiagnnięcie dalszego postępu w naszym procesie akcesyjnym leży w interesie wszystkich stron. Niemniej, pomimo naszych niestrudzonych starań, cały proces akcesyjny uległ wyraźnemu spowolnieniu z powodu oporu i politycznych przeszkód ze strony niektórych państw członkowskich. Pomimo tego, jesteśmy bardzo zaangażowani $\mathrm{w}$ nasz proces akcesyjny oraz plan reform. Uważamy ten kierunek za nieodwracalny. W ten sposób pragniemy zapewnić naszym obywatelom najlepsze prawo oraz najwyższy standard w każdej sferze codziennego życia. Tak naprawdę w ciagu ostatnich lat zrobiliśmy wielki postęp, by to osiagnąć, a to dzięki już przeprowadzo-

20 A. Reimann, Erdogan Escalates Germany Criticism, http://www.spiegel.de/international/europe/0,1518,795423,00.html (14.11.2011).

212003 Regular Report of the European Council on Turkey's Progress Towards Accession, s. $5-6$.

${ }^{22}$ Ibidem, s. 6. 
nym, wielu złożonym reformom” "23. W dalszej części wywiadu Ahmet Davutoğlu powiedział: „Przystapienie do Unii Europejskiej jest i pozostanie naszym strategicznym celem. [...] Pomimo naszych starań, negocjacje przebiegają powoli ze względu na sprzeciw i polityczne przeszkody stawiane przez niektóre państwa członkowskie. Niemniej, jesteśmy zdecydowani kontynuować proces akcesyjny, realizować kolejne reformy i jest to nieodwracalny kurs ${ }^{24,}$.

Z kolei Egemen Bağış, główny negocjator ze strony Turcji podkreślił: „Turcja nie będzie problemem. Turcja będzie częścią rozwiązania, którym Europa stawia czoła, począwszy od ekonomii na ochronie środowiska naturalnego kończąc, od energetyki do bezpieczeństwa. [...] Turcja jest remedium na tak zwane zderzenie cywilizacji. Unia Europejska nie będzie pełna bez przyjęcia Turcji i z tego muszą sobie zdawać sprawę liderzy po obu stronach"25. Jednocześnie należy wspomnieć, że nastawienie samego premiera, a zarazem lidera AKP Recepa Tayyipa Erdoğana nie zawsze było euroentuzjastyczne. Jeszcze jako członek Refah Partisi, uważanych przez niektórych za poprzedniczkę AKP, Erdoğan sceptycznie oceniał zarówno samą ideę integracji europejskiej, jak i udział w niej Turcji ${ }^{26}$. Podobnie zresztą wypowiadał się także na temat funkcjonowania $\mathrm{NATO}^{27}$. Później, już jako lider i współzałożyciel AKP, zmienił zdanie i od 2002 roku opowiada się za przystapieniem Turcji do UE. W 2004 roku miał publicznie stwierdzić: „Wraz z przyjęciem Turcji do Unii Europejskiej Europa może zademonstrować, że nie jest kontynentem zderzenia cywilizacji, ale ich porozumienia i pokoju"28.

Potwierdzeniem deklaracji czołowych przedstawicieli rządu, a zarazem partii AKP, jest uwzględnienie przystąpienia do Unii Europejskiej wśród priorytetów tak zwanej Wizji 2023 (ang. The 2023 Vision). Dokument ten obejmuje szereg najważniejszych celów, które mają zostać osiagnięte przez tureckie władze do roku jubileuszowego - obchodów stulecia republiki w 2023 roku $^{29}$. Warto jednakże podkreślić, że wśród celów znalazł się także rozwój integracji regionalnej o charakterze gospodarczym oraz z zakresu bezpieczeństwa ${ }^{30}$.

Przedstawione wcześniej argumenty oraz wypowiedzi czołowych polityków AKP są jednak podważane przez opozycję, a zwłaszcza przez przedstawicieli kemalistowskiej Republikańskiej Partii Ludowej (CHP - Cumhuriyet Halk Partisi). CHP nieodmiennie podkreśla konieczność zachowania podstawowych zasad kemalizmu (republikanizm, nacjonalizm, populizm, etatyzm, laicyzm), które, w przekonaniu jej liderów, zostały

23 C. Aksoy, A Vision Without Borders, „The Turkish Perspective” March-April 2011, s. 45.

24 Ibidem, s. 45.

25 E. Bağış, State of Play in Turkish-EU Ties: Turkey Remains Firm on EU Path, „Turkish Review" 2011, vol. 1, Issue 2, s. 39.

${ }^{26}$ Islamistyczna Refah Partisi (Partia Dobrobytu) została założona w 1983 roku. Na jej czele stał polityczny nauczyciel Recepa Erdoğana - Necmettin Erbakan. RP współtworzyła rząd w latach 1996-1997. Partia została zdelegalizowana w 1998 roku, ponieważ uznano, iż jej działalność stanowiła zagrożenie dla sekularnego charakteru państwa.

27 The Muslim World After 9/11, pod red. I. Lesser i inni, RAND Corporation, s. 196.

28 Erdogan named European of the Year, http://arsiv.ntvmsnbc.com/news/298717.asp?cp1=1 (14.11.2011).

29 Podstawy programu Wizja 2023 obejmują rozmaite cele polityczne, gospodarcze oraz społeczne.

30 A. Davutoğlu, Turkey's Zero Problems Foreign Policy, „Foreign Policy”, 20 May 2010. 
zagrożone po przejęciu władzy przez Partię Sprawiedliwości i Rozwoju ${ }^{31}$. Lider CHP Kemal Kilıçdaroğlu w jednym z wywiadów ostro skrytykował europejską politykę AKP słowami: „Dzisiaj AKP tylko mówi o procesie akcesyjnym i stara się zrzucić całą winę na naszych partnerów z UE. Prawda jest taka, że AKP niezbyt komfortowo czuje się w ramach społeczności euroatlantyckiej. Lepiej czuje się w innych regionach takich jak chociażby Bliski Wschód. Jednak z drugiej strony, poprzez realizację swej polityki oraz ciągłe odniesienia do czasów osmańskich, cały czas wprowadza niepokój w tych regionach. [...] Szczerze mówiąc, uważam że polityka eliminacji problemów z sąsiadami, realizowana przez rząd AKP, nie tylko się nie sprawdziła, ale nawet zwróciła przeciwko nam. Wszystko przed nami, ale jej skutki już są widoczne, na przykład, pogorszenie w relacjach z Azerbejdżanem" ${ }^{\text {"32 }}$. Wypowiedzi polityków CHP tylko potwierdzają obiegowe opinie wśród przeciwników AKP, którzy zarzucają tej partii świadome dążenie do pogorszenia stosunków ze Stanami Zjednoczonymi i Unią Europejską oraz koncentrację jedynie na rozszerzaniu strefy wpływów w świecie islamskim, a w szczególności na Bliskim Wschodzie. Jednakże, jak zauważa Joanna Sztubert, „choć nie należy przeceniać znaczenia powiązań kulturowych i religijnych Turcji z państwami muzułmańskimi, to jednak nawet ich najsłabszy wpływ zwiększa zdolność do pośredniczenia w relacjach z Unią Europejską, szczególnie w sytuacji jej słabej identyfikacji w regionie bliskowschodnim. Specyfika Turcji polega na tym, że przy ocenie jej charakteru nie znajduje zastosowania metoda bezpośredniego i wyłącznego odwoływania się albo do rozwiązań zachodnich, albo do właściwych dla społeczności islamskich"33.

Bardzo krytyczne stanowisko wewnętrznej opozycji nie zmienia faktu, iż to właśnie za rządów AKP od 2002 roku Turcja dokonała największego postępu na drodze do członkostwa w UE. Co więcej, to właśnie fakt udziału w procesie integracji europejskiej oraz presja ze strony Brukseli na rozwój demokratyzacji w Turcji sprawiły, że AKP, pod hasłem wypełniania kryteriów kopenhaskich, zaczęła stopniowo pozbawiać armię wpływu na wewnętrzną sytuację polityczną ${ }^{34}$. Do początku XXI wieku szerokie wpływy armii oraz brak cywilnego zwierzchnictwa stanowiły jeden z podstawowych zarzutów pod adresem władz w Ankarze. Przed AKP żadna partia nie podejmowała tak śmiałych i, co najważniejsze, tak skutecznych działań wymierzonych w wojskowych. Tymczasem członkowie Partii Sprawiedliwości i Rozwoju dostrzegli związek pomiędzy intensyfikacją stosunków z UE a możliwościami przeprowadzenia odważnych reform wewnętrznych.

Czołowi członkowie Partii Sprawiedliwości i Rozwoju, na czele z przedstawicielami najwyższych władz państwowych, konsekwentnie podkreślają, iż członkostwo Turcji w UE pozostaje najważniejszym celem tureckiej polityki zagranicznej, pomimo

31 Zob. S. Kili, The Atatürk Revolution: A Paradigm of Modernization, Istanbul 2008, s. 193-258. Warto nadmienić, że powszechnie stosowany w polskiej literaturze przedmiotu termin kemalizm jest odpowiednikiem tureckiego terminu atatürkçülük - dosłownie ataturkizm.

${ }_{32}$ Interview with Kemal Kılıçdaroğlu, ,,Turkish Policy Quarterly” Winter 2010/11, vol. 9, no. 4, s. 25.

33 J. Sztubert, Znaczenie Turcji dla relacji Unii Europejskiej z Bliskim Wschodem, w: Turcja i Europa. Wyzwania i szanse, pod red. A. Szymańskiego, Polski Instytut Spraw Międzynarodowych, Warszawa 2011, s. 172-173.

34 D. Lovell, Turkey in Europe: Record, Challenges and the Future, „Insight Turkey” 2011, vol. 13 , no. 3, s. 183 . 
wielu trudności oraz niezwykle powolnego tempa prowadzenia rozmów. W jednej ze swych wypowiedzi z 2010 roku Prezydent Abdullah Gül dobitnie zaprzeczył jakoby poprawa pozycji Turcji na Bliskim Wschodzie musiała być równoznaczna z zaniedbywaniem dobrych relacji z Zachodem: „Uważam za bardzo błędne takie interpretacje poszczególnych interesów Turcji w innych częściach świata, które zakładają że Turcja oddala się od Zachodu, obraca się plecami do Zachodu lub szuka alternatywy dla Zachodu. Turcja stanowi część Europy”35.

Jednocześnie tureckie władze konsekwentnie odrzucają stanowiącą alternatywę dla pełnoprawnego członkostwa koncepcję uprzywilejowanego partnerstwa, zaproponowaną przez kierownictwo niemieckiej CDU w 2004 roku. Angela Merkel, już jako kanclerz Niemiec, nie wspominała wprost o takiej możliwości, wyraźnie akcentując, że szanuje i zamierza przestrzegać postanowień wszelkich wcześniejszych umów zawartych z Turcją, a także decyzję Rady Europejskiej o rozpoczęciu negocjacji akcesyjnych. Niemniej ideę podchwycił prezydent Francji Nicholas Sarkozy. Jak zauważył Adam Szymański, można wyróżnić kilka podstawowych założeń wspomnianej koncepcji. „Po pierwsze, uprzywilejowane partnerstwo oznaczałoby postęp w integracji gospodarczej Turcji z UE dzięki przyznaniu czterech swobód rynku wspólnotowego. Po drugie, partnerstwo to zakładałoby włączenie Turcji do udziału w niektórych politykach wspólnotowych, z czym wiązałby się rozwój indywidualnych programów pomocy. Po trzecie, koncepcja ta umożliwiłaby uczestnictwo Turcji w inicjatywach w ramach Wspólnej Polityki Zagranicznej i Bezpieczeństwa UE. [...] Po czwarte, uprzywilejowane partnerstwo przewidywałoby wzmocnienie współpracy urzędów i instytucji wymiaru sprawiedliwości i spraw wewnętrznych, na przykład, w takiej dziedzinie jak zwalczanie terroryzmu"36. Prezydent Turcji Abdullah Gül, jeszcze jako minister spraw zagranicznych, określił koncepcję uprzywilejowanego partnerstwa mianem „,bezpodstawnej i niemoralnej” ${ }^{37}$. Równie negatywnie ocenił ją premier Erdoğan: „Turcja nie może zaakceptować stanowiska Niemiec i Francji. Pojęcie uprzywilejowanego partnerstwa nie istnieje nawet w europejskim prawie. Niektórzy ograniczeni politycy wykorzystują Turcję do doraźnych celów wyborczych. Uważamy to za bardzo złe, za populistyczne. My nigdy się nie poddamy. Zachowujemy spokój. Odrabiamy pracę domową i wciąż idziemy naprzód"38.

\section{Wnioski}

Obecną politykę zagraniczną Turcji można z pełnym przekonaniem określić mianem prozachodniej, chociaż przy jednoczesnym zastrzeżeniu, iż w przeciwieństwie do okresu sprzed 2002 roku nie jest ona wyłącznie prozachodnia. W pierwszej dekadzie

\footnotetext{
35 Ibidem, s. 178.

36 A. Szymański, Niemcy wobec rozszerzenia Unii Europejskiej o Turcję, „Materiały studialne Polskiego Instytutu Spraw Międzynarodowych" 2007, nr 4, s. 17.

37 Turkey and Europe: the Way Ahead, International Crisis Group, Europe Report No. 184 of 17 August 2007, s. 42.

38 Erdogan criticizes Germany, France for blocking Turkey's EU bid, http://eurodialogue.org/ Erdogan-criticizes-Germany-France-for-blocking-Turkey-EU-bid (14.11.2011).
} 
XXI wieku kolejne rządy, zdominowane przez członków Partii Sprawiedliwości i Rozwoju, konsekwentnie realizują główne założenia nowej polityki zagranicznej Turcji, której podstawę stanowi koncepcja ministra spraw zagranicznych Ahmeta Davutoğlu (doktryna Davutoğlu). Pełnoprawne członkostwo w Unii Europejskiej, przynajmniej oficjalnie, nadal pozostaje głównym jej celem. Jednocześnie Turcja odzyskuje wpływy utracone na obszarze postosmańskim po upadku Imperium, a także buduje nowe, chociażby w Azji Centralnej.

Wspomniane działania mają nie tylko wzmocnić pozycję Turcji na arenie międzynarodowej w wymiarze regionalnym, ale także podnieść jej atrakcyjność polityczną i ekonomiczną w oczach czołowych polityków UE. Bez wątpienia Turcja, posiadająca rozległe wpływy i ciesząca się prestiżem w świecie muzułmańskim, będzie dla Unii o wiele wartościowszym partnerem aniżeli Turcja zdominowana przez armię i skłócona z sąsiednimi państwami. Niepokojem może jednak napawać fakt bardzo powolnego postępu negocjacji akcesyjnych lub, mówiąc wprost, brak jakiegokolwiek postępu. Twierdzenie, iż do przełomu w rozmowach nie dojdzie tak długo jak długo nie uda się uregulować kwestii cypryjskiej, wydaje się być uzasadnione. Świadczy o tym trwające od 2006 roku zawieszenie rozmów w ramach aż ośmiu rozdziałów negocjacyjnych. Póki co, sytuacja polityczna na Cyprze nie sprzyja konstruktywnemu dialogowi. Można odnieść wrażenie, iż żadnej ze stron nie zależy na rozwiązaniu sporu. Rząd AKP znalazł się w patowej pozycji. Z jednej strony nie może przyspieszyć rozmów z UE bez porozumienia na Cyprze, natomiast $\mathrm{z}$ drugiej strony musi liczyć się z opinią publiczną i nie może zająć zbyt elastycznego stanowiska w tej sprawie. Spór cypryjski nadal jest zaliczany przez Turków do grupy żywotnych interesów państwa, kluczowych z punktu widzenia jego bezpieczeństwa. Po upływie blisko czterdziestu lat od tureckiej interwencji na wyspie, wszelkie ustępstwa lub wręcz wycofanie się z wyspy zostałyby potraktowane przez większość społeczeństwa jako porażka, dyshonor ${ }^{39}$. Wpływy armii oraz kemalistów, chociaż już o wiele słabsze niż w 2002 roku, nadal pozostają silne. Co więcej, to właśnie za rządów AKP można zaobserwować wzrost nastrojów nacjonalistycznych, poczucia dumy z przynależności narodowej w tureckim społeczeństwie.

Wskazane byłoby większe zaangażowanie ze strony Unii Europejskiej najpierw w proces regulacji kwestii cypryjskiej, a następnie dopiero w sam proces negocjacji akcesyjnych z Turcją. Jednakże pojawia się pytanie czy w obecnej sytuacji, w obliczu kryzysu finansowego i narastania niechęci rządów najbardziej wpływowych państw członkowskich wobec dalszego rozszerzania Unii, taka konstruktywna zmiana po stronie UE jest w ogóle możliwa.

Jednym z trzech głównych celów polskiej prezydencji w Radzie Unii Europejskiej w drugiej połowie 2011 roku było większe otwarcie Unii w kontaktach zewnętrznych oraz czerpanie korzyści z tego otwarcia. Polska prezydencja sprzyjała także tureckim aspiracjom członkowskim - Polska jest jednym z państw opowiadających się za przystąpieniem Turcji. W jej programie zapisano nawet, że Polska ,wykorzysta wszelkie możliwości kontynuowania negocjacji akcesyjnych z Turcją. Nowoczesna Turcja,

39 W literaturze tureckiej na określenie interwencji wojsk tureckich na Cyprze z 1974 roku najczęściej używa się terminu operacja pokojowa, podczas gdy Grekocypryjczycy używają pojęć inwazja lub agresja. 
silna gospodarczo i rozwinięta społecznie, wzmocniłaby Unię Europejską̧" ${ }^{40}$. Jednakże prawdziwym testem dla Unii będzie dopiero prezydencja cypryjska. Jeśli premier Recep Tayyip Erdoğan postąpi zgodnie z wcześniejszymi deklaracjami i jednostronnie zawiesi negocjacje z UE, decyzja ta może stanowić koniec rokowań i fiasko całego projektu rozszerzenia o Turcję. W takiej sytuacji potwierdziłyby się obawy tureckiej opozycji, a także ostrzeżenia dotyczące istotnych rozbieżności pomiędzy deklaracjami a rzeczywistymi działaniami podejmowanymi przez polityków AKP. Niemniej należy jeszcze raz wyraźnie podkreślić, iż to właśnie za rządów Partii Sprawiedliwości i Rozwoju Turcja dokonała największego postępu na drodze do pełnoprawnego członkostwa w UE. Determinacja tureckich władz w dążeniu do pełnoprawnego członkostwa w UE znajduje także potwierdzenie w zaliczeniu jej do priorytetów rządowego programu Wizja 2023 oraz zdecydowanym odrzuceniu alternatywnej koncepcji uprzywilejowanego partnerstwa.

\section{Abstract \\ European integration in Turkey's foreign policy during the time of the Justice and Development Party's (AKP) rule}

At the beginning of the 2010s, Turkey is certainly among the key states enjoying the status of a regional power. Turkish policy influences nearly all its neighbors, as well as almost the entire Muslim world. It is no coincidence that the participants of the Arab Spring of 2011 appreciate the achievements of the Turkish government, while the present Prime Minister Recep Tayyip Erdoğan is slowly emerging as a hero among the Tunisians, Egyptians or Palestinians. Has the pro-European policy of Turkey evolved and can any regularities or changes be observed? It is also worth answering the question of whether all the factions of the ruling AKP party support the integration of Turkey with the EU. The present foreign policy of Turkey can be positively described as pro-Western, however a reservation is required that the policy is no longer exclusively pro-Western, unlike before 2002. Successive governments ruling Turkey in the 2000s were dominated by Justice and Development party members, who consistently implemented the main assumptions of Turkey's foreign policy, founded on the concept developed by the Minister of Foreign Affairs, Ahmet Davutoğlu (Davutoğlu's doctrine). Its primary goal, at least officially, is full membership of the European Union. Turkey is simultaneously regaining its influence in the post-Ottoman territories, lost following the fall of the Empire; it is also building a new sphere of influence in Central Asia, among other places.

40 Program of the Polish Presidency of the Council of the European Union, Ministry of Foreign Affairs, Warsaw 2011. 